\title{
Money and Literature
}

\author{
Elizabeth Edwards
}

The topic of money and literature opens a subject broad and deep: not only are there a number of approaches that could be used, and a vast array of possible texts to consider, but there are immediate complications such as the medieval status of a category such as "literature". For example, there is a little FrenchFlemish dialogue, translated by Caxton into English, which also exists in versions in Middle Dutch and Middle German; it is primarily a language manual, but includes lessons in how to calculate exchange rates in different currencies - but insofar as it has characters, rhyme, and a certain pleasing if rough form, it could arguably be both literature and an important historical source for understanding the currency market. ${ }^{1}$ However, in the space offered here, I shall take "literature" to mean mainly the high-culture products of poets such as Dante and Chaucer, together with the recognized genres of the period.

My remarks will of necessity be confined to the high and late Middle Ages, and to literature mainly in French and English. I characterize a literary approach, on the part of both medieval authors and modern critics, as fundamentally a consideration of the meaning of money, in terms not of its face value or purchasing power, but its psychological and symbolic significance. For if anything is characteristic of the literary approach, it is the consideration of works in terms of what I will call hyper-economies: those systems of desire, social prestige, metaphoric or symbolic significance, and even sexual drive that attend any actual financial transaction. Thus literature concerns itself with the psychically and morally charged domains of desire, greed, envy, satisfaction, prestige, and magnificence that, no doubt, continue to mark our own relation to our own money.

I will begin by setting out some of the approaches taken by literary scholars to the question of money, including the field of "new economic criticism", as it is called by Martha Woodmansee and Mark Osteen in a valuable essay collection. $^{2}$ The remainder of this chapter will be demonstrative; relying on the work of critics in the field, I will give brief samples of the literary criticism

1 Discussed in Howell, Commerce before Capitalism, pp. 19-22.

2 Woodmansee and Osteen (eds.), The New Economic Criticism. 
of money: first, in relation to the trope of plenty - the mysterious increase of money - across the two great genres of fabliaux and romance. Next, I will consider the meaning of money in the very dense symbolism of Dante's Commedia, and finally I will turn to a consideration of what golden money meant to Chaucer in the age Peter Spufford calls "the victory of gold". 3

The approaches taken to texts by critics can be characterized as follows: representation; conditions of production and consumption; reflective or speculative; and theoretical. ${ }^{4}$ The first looks at representations of money and its uses. Literature, like other texts, provides a valuable testimony to the status of money; Chaucer's Shipman's Tale offers a splendid example in its account of trading shields against franks (francs) in Paris and Bruges. Gerhard Joseph gives a cogent account of the research on the path to profit as the merchant borrows franks in Paris to pay debts incurred in "shields" (or ecus), a money of account that was not an actual currency or coin. ${ }^{5}$ Other critics follow the economics of the production of literature, considered both from external documents and historical evidence, as in Richard Firth Green's Poets and Princepleasers, and from the internal evidences of the needy poet and the "complaint to the purse" genre, of which Thomas Hoccleve provides the most outstanding English example. In particular, new historicist criticism reads non-literary texts to produce an account of the social forces that inflect the literary work in question.

By "reflective or speculative", I mean two things. The first is the research that shows the reflection of, for example, scholastic theories of money or economics in literary texts. A classic example is Jill Mann's “Price and value in Sir Gawain and the Green Knight", which accounts for the commercial language in a highly courtly poem. ${ }^{6}$ But in addition, many literary works are highly speculative, themselves presenting theories of money and economic life. The best example is William Langland's Piers Plowman and the tradition it initiated - it presents a complex account, one it is not possible to do justice to here. John Gower's Confessio Amantis and even Le Roman de la Rose likewise "perform" economic theory in poetic form. By "theoretical," I mean the way in which economic theories open up literary texts to interpretation. This final category, then, is a way of reading.

3 Spufford, Money and Its Use, ch. 12.

4 Some of these are close to Woodmansee and Osteen's categories - "Production", "External Circulation and Consumption", "Internal Circulation", and "Metatheoretical" - in "Taking account of the new economic criticism", pp. 35-39.

5 Joseph, "Chaucer's coinage", pp. 347-48 and fn. 16.

6 Mann, "Price and value in Sir Gawain and the Green Knight". 
In particular, postmodern economic theories have been of the utmost importance in contemporary criticism. These theories include Marcel Mauss's early work on the gift; Jean-Joseph Goux's incendiary work on symbolic economies, in which he reads economics through Marx and Freud; Jean-François Lyotard's notion of libidinal economy as the distribution of sexual energy inside other economies; Georges Bataille's "general economy", a theory of sumptuary expenditure, of excess rather than scarcity as the root economic "problem"; and Pierre Bourdieu's theories of social capital in honour and prestige cultures. Literary critics often follow the seminal 1978 work of Marc Shell, The Economy of Literature, which argues that literary language is itself an economy of tropes, signs, and exchanges, and that "the economy of literature seeks also to understand the relation between such literary exchanges and the exchanges that constitute the political economy".7

Jack L. Amariglio and David Ruccio consider whether these understandings of "economy" in postmodern theory are meaningful to real economists, and offer a helpful critical account, concluding that these "hyper-economies", as I will call them, do have something to contribute to the dismal science, to challenge "the maxims of rational economic behaviour, particularly maximization of expected utility". ${ }^{8}$ It is not surprising to a medievalist to find that money always had moral and libidinal understandings that supplemented the simple Aristotelian account of money as a means and a medium of utility. Thus the economies of desire, expenditure, and exploitation in modern theory map well onto the medieval understanding, with perhaps the exception of the religious economy of salvation that in a sense regulated the earthly economies of exchange and lack. "Economy" is a large term, and while the present essay largely limits itself to instances of money in literature, many discussions of money occur in works with a larger vision of literature and economics. An outstanding example is D. Vance Smith's Arts of Possession: The Middle-English Household Imaginary, which presents, through exemplary readings of literary texts, a holistic picture of the oikos, the role of the political household, the meaning of money, and the social imaginary in which expenditure took place.

At a step down from considerations of the whole economy, there is a general understanding among literary critics that the link between language and money is close, and that this is chiefly because both are sign systems. Key texts include Aristotle's influential account in Nicomachean Ethics, Book 5, of money's having been established by convention, and Augustine's similar argument

7 Shell, The Economy of Literature, p. 7 .

8 Amariglio and Ruccio, "Literary/cultural 'economies', economic discourse, and the question of Marxism", p. 387 . 
about language as a sign system of "human institution" in De Doctrina Christiana, Book 2. The prevalence of semiotic theory in 2oth-century thought is in some ways congruent with, and caused a reinvestigation of, medieval sign theory. Sign theory forms the basis of several important works on medieval coins and literature, including that of R.A. Shoaf, whose work on the meaning of money for Dante and Chaucer remains an important commentary. ${ }^{9}$ Andrew Cowell's book At Play in the Tavern: Signs, Coins, and Bodies in the Middle Ages launches an ambitious argument that the literature of the tavern, a literature often scurrilous, satirical, and sexual, in an urban, mercantile, and profitdriven setting, provides an alternative to the ecclesiastical understanding of signs as requiring fixity. The tavern represents the rising profit economy of the later Middle Ages, and sets the stage for the shifting monetary exchange value sign that refuses the "concept of fixed community value and semiotic stability". ${ }^{10}$ The notion that money dissolves fixed meanings and replaces older forms of community is widespread, whether it is celebrated, as by Cowell, or seen as a problem. Shoaf sees both Dante and Chaucer as anxious about the slipping away of stable reference for signs, which money exemplifies, for money, as is clear from Aristotle, "is the more or less temporary disappearance of difference"11; it dissolves the character of things in replacing them with abstract exchangeability. I shall return to this point in conclusion, but at present will simply stress that this conception of money (as fungible, dissolving, shifting) is reflected in the structure of genres of medieval literature; "courtly" and aristocratic works such as romance and epic tend to preserve a vision of a gift economy, which obscures monetary transactions, while genres such as the fabliaux represent the fun that money can bring.

\section{Money and Plenty/Plenty of Money}

Narrative characterizes literature, and literature provides a narrative about the origin of money that runs alongside the widespread Aristotelian account of convenience and convention. This is a story of a golden age of plenty and fulness of being, a world without want in part because of the simplicity of human life, in part because of the fecundity of nature, when, as Chaucer puts it in

\footnotetext{
9 Shoaf, Dante, Chaucer and Currency of the Word.

10 Cowell, At Play in the Tavern, p. 250.

11 Shoaf, Dante, Chaucer and Currency of the Word, p. 12.
} 
"The Former Age", the "corn up-sprong, unsowe of mannes hond".12 This age is violently interrupted by shortage and yields gradually to "modern" economics of profit, avarice, deceit, and coin-making. The story appears in Metrum v of Book II of Boethius' Consolation of Philosophy, and very influentially in Jean de Meun's Roman de la Rose. All versions propose a world without riches, and therefore without covetousness and war, and place the fall of man in the invention of riches, gold and precious gems and stamped coins, at the point when (in Chaucer's words) "men first dide hir swety bysiness/To grobbe up metal, lurkinge in darknesse" (ll. 29-30). In the time of plenty, ships did not sail, for there was no need to ship anything. Money partakes of the logic of distance and absence; money stands in for something not present. It is thus an intrinsic part of the lack that causes war, hoarding, and avarice.

Chaucer's contemporary John Gower makes his well-known attack on money in Book v of Confessio Amantis. This work is a long (very long) poem taking the form of a dialogue between Amans and his confessor, full of embedded narrative exempla, and Book v's explicit topic is avarice, which is to say, the false love of goods or money. Gower's account of avarice is radical in the blame he puts on money itself - it is not a good or even a neutral thing distorted by the vice, but itself is the cause. It is when "men knewen the moneie/Tho wente pes out of the weie/And werre cam on every side".13 Further, "Tofor the time, er gold was smite/In coign, that men the florin knewe/There was welnigh noman untrewe" (v. 334-36). As Robert Epstein writes of these lines, "the problem is money itself: the intentional, artificial abstraction of wealth". ${ }^{14}$ Gower's argument is that wealth is an accumulation, and as such is a paradoxical form of poverty, for the hoarder cannot spend his riches without diminishing his wealth. Instead, he is condemned to continuous anxiety and care for the protection of what he cannot spend and of which he cannot ever get enough. Confessio Amantis exemplifies these moral points about money with helpful narratives illustrating various subsets of Avarice. These include a high number of sins and vices more ordinarily considered sexual. This coincidence of the monetary and the sexual is very frequent in the literature of the period here considered. Just after the first story, that of Midas, the Confessor turns to the question of sexual Jealousy. He makes the connection with Avarice explicit at

\footnotetext{
12 Chaucer, The Former Age, l. 10. All references to Chaucer are to The Riverside Chaucer, ed. L.D. Benson.

13 Gower, Confessio Amantis v. ll. 11-13. All citations of Gower are to The English Works of John Gower, ed. G.C. Macaulay.

14 Epstein, "Dismal science", p. 226.
} 
v. 1l. 595-610: these vices are alike because neither has any peace or joy in its possessions, money or spouse. Sexual hoarding is just like hoarding money.

Other works of literature attest not to a lost era of plenty, but to a proliferation or increase in money and profits, often brought about by expenditure. The question of money is inflected by genres, some of which are more prone to discuss it than others, and in particular those that Andrew Cowell calls "comicorealist" - the literature of the tavern, the genre of the fabliau, the comic tale. These genres are often contrasted with the more courtly or martial settings of romance or epic; these tend to efface the money economy while presenting an economy of the gift and of aristocratic largess. While the representation of monetary transactions is perhaps more prevalent in "comico-realism," I will instead stress figurations of money that transcend generic boundaries: the phantasy of a plenitude that overcomes lack, the fairy origin of money, and its unnatural proliferation.

It is impossible to talk about the meaning of money in medieval literature without talking about sex. Many comico-realist stories show the "profits" that can be made by circulation alone, and many of these profits are sexual, or "in kind" rewards in excess of the basic monetary transactions. In both Chaucer's Reeve's Tale and Shipman's Tale, for example, when money moves, sexual profits accrue. Unlike the hoarding situation of Gower's Avarice, spending is proposed as the road to plenty. In the Reeve's Tale, two clerks are anxious that they will be robbed by a suspect miller; he tricks them by loosing their horse, and robs them anyway of half a bushel of grain. The clerks decide to accept the inevitable, but in the course of an evening spent at the miller's home manage to convert their losses into sexual pleasure with the women of the house. While Alan the clerk expresses the theory of "equivalence in kind" directly - "gif a man in a point be agreved,/That in another he sal be releved" (4181-82) - in fact the clerks get the sex and the flour back too. This is the typical comic pattern of total restitution and added profit but of additional interest is the moment when the previously thrifty clerks, apparently conceding their losses, offer up a goose dinner and a good quantity of ale: "Lo, here oure silver, redy for to spende" says John (4135), marking the turn towards the denouement with an extraordinary and unnecessary festive expenditure. ${ }^{15}$ Spending is the sovereign remedy; the clerk's anxiety and stinginess gives way to a general economy of abundance and expenditure.

15 As I have argued at greater length in Edwards, "The economics of justice in Chaucer's Miller's and Reeve's Tales", pp.10o-1. 
The 13th-century French fabliau Trubert shows a fantastic set of bartering and exchanges that begins badly for the vilain protagonist because he misunderstands the conversion value of different denominations of money. Setting out to sell a calf, but thinking that there are twenty deniers in a sou, rather than twelve, he accepts one bad bargain after another on a path that seems destined to lead to destitution. However, when a chance encounter over a painted goat brings him into contact with the aristocracy, everything is reversed. Now his bargains involve a sexual component: he bargains with the Duchess for the goat at the price of "un foutre et cinc sous de deniers"16 [a shag and five sous of deniers]. The story is fuelled by the notion of slippage and proliferation inside exchange rates, and plays on the simple notion that money is partitive - there might be any number of deniers in a sou. There is not one unit of currency, but many, and what is included in any price turns out to be entirely negotiable. In a complicated narrative of unmotivated class malignancy, Trubert goes on to profit mightily from his tricks, all accompanied by sexual conquests. Sexual pleasure is the fantastic supplement to financial profit, culminating in a scene in which Trubert, now disguised as a woman in her marriage bed with a king, catches the king's penis in "une borse grant et parfonde" (1. 2767) [a purse large and deep] and strangulates it by pulling the purse strings. Part of the entertainment here is that borse is slang for the male testicles in many, many fabliaux, yet here it is doing duty as a simulacrum of the female con; thus, as Simon Gaunt writes, the word-play is "exploiting linguistic indeterminacy and making it analogous to gender indeterminacy". ${ }^{17}$ It is also catching the phallic equipment within the economic paradigm which sets the story going, the question of what is in one's purse.

The scurrilous and smutty configurations of money are sometimes held to be characteristic of the "lowly" genre of fabliaux-type tales. At the nadir, money is associated with flatulence and faeces, as shown in the Summoner's Tale where the greedy Friar's "payment" is a fart, and more amply demonstrated in the "Shitting Ducats" chapter of Valerie Allen's On Farting. These comicorealist genres are contrasted with others, particularly romance. Romance, of course, is held to be the genre farthest from "realism", a genre that reflects a world valourizing aristocratic self-image, and since Erich Auerbach, as erasing and mystifying the real economic functions of the class it represents. However, I will briefly argue that romance also establishes a mythos of plenty, of fantastic expenditures and the strange proliferation and breeding of money.

16 Trubert, ed. de Lage, l. 156.

17 Gaunt, Gender and Genre in Medieval French Literature, p. 250. 
The most obvious romance to consider is Marie de France's 12th-century lai of Lanval, in which a fairy mistress gives a poor knight the wherewithal to spend as he likes on the condition that he never boast of her or even mention her existence; "Cum plus despendres richement/[E] plus avrat or e argent" [the more lavishly he spends, the more gold and silver he will have]. ${ }^{18}$ Needless to say, he breaks the one rule given him, suffers calumny and persecution, and in the end is restored to plenitude in an extravagant act of restitution and vindication when the lady reveals herself to Arthur's court. The vindication is indeed so total that it is difficult not to read this text psychologically as a compensatory fantasy; the neglected knight/child is able to demonstrate publicly that rather than lacking everything, he has it all - the most beautiful mistress ever seen, fairy gold, revenge on all his enemies - so it is not surprising that he disappears entirely into the realm of fairy at the end of the tale. Lanval is the original example of the "poor knight", a typical figure in romance, for example Balin le sauvage in the 13th-century Suite de Merlin and in Malory's Morte d'Arthur, or in Sir Isumbras or Sir Amadace.

In comparing Marie's Lanval with the late-14th-century English Sir Launfal, Vance Smith writes: "Marie's version ... emphasizes what we could call the erotics of feudal magnificence". ${ }^{19}$ Magnificence is a hallmark of a feudal gift economy, where social bonds are realized in gifts, and are set in an aristocratic economy of rich commodities and adornments. ${ }^{20}$ The poem proposes spending as the only economic activity, and fairy gold as the only origin of the money to spend. Smith provides a rich and nuanced reading of the ways in which the later poem, still generically committed to the romance "enchantment" of the economic base, nonetheless "subsumes the explicit forms of and concerns with social capital in Marie's story to the more pressing and urgent concerns of real capital ..." ${ }^{21}$ While the later version supports the original's view of the aristocratic gift economy, one founded on courtly largess, on the giving of presents and clothing to supporters and the distribution of alms, it also subverts it, intentionally or not, by representing all the precise modes of calculation and economy that go into the ability to give. Thomas Chestre's Sir Launfal is indeed poor because he has given great gifts: "He gaf gyftys largelyche,/Gold and sylver

18 Marie de France, Lais, ed. A. Ewert, ll. 140-41.

19 Smith, Arts of Possession, p. 158.

20 The beginning point for an economics of the gift is Marcel Mauss' "Essai sur le don" of 1923. The collection assembled by Alan Schrift in The Logic of the Gift provides the best entrance to the debates on the topic, with essays by Claude Levi-Strauss, Marshall Sahlins, Pierre Bourdieu, Jacques Derrida, and Marilyn Strathern.

Smith, Arts of Possession, p. 164. 
and clothes ryche". ${ }^{22}$ We are told that in one year "So saveglych hys good he besette/That he ware yn greet dette" (130-31), where the key word "savagely" hints that divesting himself of his goods is almost a frenzy.

While in Marie's version the mode of transmission of the gold is not specified, in the English reworking Launfal is given a magical alner (purse) with a precise, if impressive, withdrawal amount of a mark of gold (1.323). After blurting out the secret of the fairy, the first thing he does is check the alner - which, alas, is empty (1. 736). The poem demonstrates a problem with the limits of largess. The purpose of money is, as in the fabliaux, to spend it, that is clear; but what distinguishes the Aristotelian mean of generosity (largess) from profligacy, from the "wasting" described in a nearly contemporaneous poem, Wynner and Waster? Sir Launfal works hard to maintain the carefree model of earlier romance, while encoding a great deal of anxiety about wealth and status in a changed economic era. It would be possible to continue this story with an account of other Middle English romances of economics, such as Sir Amadace and Sir Isumbras, which also raise precise questions of money, before solving them with a return to supernatural restitutions.

I have argued that two often-contrasted genres show a surprising congruence in their theory of money as productive when in circulation. Both involve spending to get, and an important part of what they get is sexual profit. They both attest to the libidinal meaning of money. The next section turns to Dante, which is also a turn from narrative representation to the matter of literary symbolism.

\section{The Meaning of Money}

Dante's Commedia provides vivid examples of ways in which money does not simply "mean" its exchange value. An economic theorist as much as a political, poetical, and cosmographical commentator, Dante thinks of the role of money in society in deeply literary ways. He follows largely on scholastic understandings of money, especially by Thomas Aquinas, but these theories come to life, take on characters, and speak. Simply put, for Dante money is one of the goods of community. It is part of what enables trusting relations of mutuality between members of the same city-state, res publica, or empire. It is because money only works by mutual agreement, trust, and credence that it appears in Canto 24 of Paradiso as an appropriate metaphor for faith itself. Corruption in 
monetary matters, easy to fall into as a routine venality, is then actually a vitiating corruption of the very fabric of trust and community itself (including, in the strongest sense, the co-communing Christians living within the same sacramental dispensation). Inferno, for example, includes hellish levels for a rich variety of economic criminals and sinners: hoarders and misers; spendthrifts; profligates; usurers; simoniacs; sellers of public office; thieves; alchemists; counterfeiters. Such is the scope of Dante's argument about the establishment of community on bonds of mutual trust that it is difficult to separate economic fraud from other types of fraud such as seduction; even the condemnation of sodomites seems to have an economic basis. The Divine Comedy presents a view of economic life deserving of longer consideration, but in this brief account I will follow only one aspect of it in the image of a single coin: the heavy symbolic freight carried by the Florentine florin.

In Dante's rich understanding, symbols work at many levels, and not even merely the four he mentions specifically in the famous letter to Can Grande, or in the opening pages of Convivio. The florin, setting the gold standard for Europe at this time, stands as a metonym for the commercial practices of Florence - and also for the greed, avarice and crass mercantilism that Dante sees as the result of those practices. This is perhaps to be expected, that any author's currency would do duty to stand for greed. But the florin is not only a symbol: it is itself inscribed with symbols, and these lead to interesting interpretive moments. On one side of the coin is a heraldic lily, with the word Florentia inscribed around it, on the other a figure of St John the Baptist in a hair shirt, his name the inscription. In Canto 13 of Inferno, in the wood of the suicides, an unknown suicide-turned-tree, mutilated by the fleeing profligate Jacapo da Sant' Andrea, delivers the following lament:

I'fui de la città che nel Batista

mutò 'l primo padrone, ond' ei per questo

sempre con l'arte sua farà trista. ${ }^{23}$

[I am of the city that changed to the Baptist from its first patron, and for this he ever grieves it with his arts.]

The "first patron" was ancient Mars, whose temple was replaced by a church to St John the Baptist. The sense is that in doing so, Florence gave up her claim to martial prowess, and suffers for it. The soul goes on to say that had not some

23 All quotations from Dante and their translations are from the editions of Inferno and Paradise by Anthony Esolen. 
fragments of the old god been preserved in the Arno bridge, the city could not have been rebuilt after its destruction by Attila. This is not so much a commendation of paganism as a criticism of his city as preferring the florin, and mercantilism, to the noble arts of Mars. It is a place of bankers and traders, not Christian soldiers.

But this is not the florin's only aspect. It is also made of gold; thus, to falsify the metal that carries communal trust is a very grave sin. It is in the last and lowest of the ditches of fraud that we find the counterfeiter, Master Adam. Swollen beyond recognition, hydroptic, and yearning for the fountains that he is cursed to remember in hell, he admits "io falsai/la lega suggellata del Batista" [I falsified the money stamped with the Baptist] (I.30.73-74) and yet still blames those who led him on and "m'indessero a batter li fiorini/ch'avevan tre carati di mondiglia" [induced me to coin the florins with three carats of dross] (I.30.89-90). Master Adam was burned by the authorities for his crime, and suffers now in the contrapasso (the suitable punishment) the irony of being burned by thirst, by the image of water. R.A. Shoaf has admirably brought out all the complexities in this image; Adam is the "old Adam", the figure of original sin that inhabits us all. As a counterfeiter, he distorted what the coin is an image of, just as he is now himself a distortion of the image of God-in-man man made in the image of God - as his distorted gross body and wasted face show. He created a substanceless simulacrum, rather than a true image - a sign backed by nothing or only by a substance infected by dross. Shoaf emphasizes Master Adam's connection with Narcissus, whose error was to fall in love with his own image, rather than to see the image of the divine in himself. ${ }^{24}$ Falsifiers and counterfeiters pose a special threat for a poet, for he too works in images; he copies nature, "coins" phrases, creates fictional (or false?) realities, and lures others to believe in such things. Dante's concern over the entire Commedia is to establish the true coin of his images; as Shoaf writes, "even as he strikes the image ("batter li fiorini"), he must strike it from reality, lest it falsify ..." 25 Many of the shades in the ditch of the falsifiers have the aspect of poetic Dopplegängers: liars like Simon, abusers of images, and alchemists such as Capocchio, "che falsai li metalli" [who made false metals] (I.29.137), who tells Dante, "e te dee ricordar ... / com'io fui di natura buona scimia" [you should remember how good an ape of Nature I was]. The poet treads a fine line between artist and ape, a mimic without substance.

24 My account summarizes Shoaf, Dante, Chaucer and Currency of the Word, pp. 24-26 and $31-36$.

25 Ibid., p. 37 . 
Thus the coins of the damned are as fallen as they themselves. Master Adam is eternally fixed in the disease of desire, of perpetual, unassuageable yearning that Dante elsewhere associates with the desire for riches. As he writes in Convivio IV.12, "when [riches] are amassed to that point, in place of satiety and refreshment, they give and produce the thirst of a feverish bosom and are not to be endured; and in the place of sufficiency, they offer a new limit ... a greater quantity to long for". ${ }^{26}$ This desire is unlike other desires; the desire for knowledge, for example, can meet with satisfaction. One final coincidence in the two places in hell I have discussed is that both are accompanied by minor appearances from the spirits of the notorious Squanderers' or Wasters' Brigade: in Canto 13, Jacapo da Sant' Andrea, who threw gold coins into the Po, and the four noblemen named at Canto 29, 124-31. If greed, avarice, and excessive desire for riches mistake the rational function of money as a means of exchange for an end in itself, the aristocratic disdain for the good of money is savagely destructive of community.

Dante returns to the florin as symbol in Paradise. Canto 18, set in the heaven of the just rulers on Jupiter, ends with a surprising turn to an invective against commerce in the Temple, in the specific form of an unnamed pope (John XXII or Boniface) who extorts money in exchange for revoking his own excommunications. This pope has forgotten Peter and Paul, because, as he says 'I' ho fermo 'I disiro/sì a colui che volle viver solo/e che per salti fu tratto al martiro" [My heart's so firmly set/on him who chose to live his life alone,/whom a dance dragged to martyrdom] (18. 133-36). Plainly this remarkable reference is to John the Baptist, the saint on the florin, and the sense is that venality has replaced the apostolic mission, that greed is the only prophet this pope knows. It is also remarkable because it is a criticism of the Baptist as one who chooses to live his life alone, that is, outside the good of community that is the aim of the just rulers on Jupiter. The florin of greed, like the Baptist, is isolated and isolating. This denunciation seems almost a non-sequitur in its location (why scold a pope in the heaven of those who deliver temporal justice?), but it makes sense on the figural level. The central image of the Canto is when the final letter M of "Diligite Iustitiam" [Love Justice] morphs first into the shape of a lily, then an eagle. Do they stand for France and then the Roman empire reborn, as many commentators think? Or is the lily the one found on the obverse side of the florin? In any case, both are frequent images on coins, and thus provide the train of associations that leads Dante to the florin, greed, and the solitary Baptist. The association is at the figural level of the poem. 
For Dante, the symbols on money are not contingent or accidental. They express something real, the real of the symbol which is the concern of literature and which should direct its users to the real point of money. Dante's fascination with this symbolism is surely unparalleled, but money has figurative power in most other poets too.

\section{"The noble yforged newe": The Gold Standard in Chaucer's Poetry}

Chaucer gives many accounts of monetary transactions, from the Summoner's attempted extortion of 12 pence from a widow in the Friar's Tale to the 500 pounds in gold spent by Aurelius on a magician in the Franklin's Tale. As Chaucer's work experience as controller of customs or Clerk of the King's Works indicates, he had deep familiarity with the finances of trade and public administration. Considerable debate has thus ensued about every particular financial instance in his oeuvre, ${ }^{27}$ though, rather surprisingly, there is no single work that addresses the totality.

In what follows I will briefly consider what gold means to Chaucer, particularly in the form of coins, by looking at its figurative use and gold as a lure that drives narrative forward in the Pardoner's and Canon's Yeoman's Tales. Metaphoric gold, like real gold, sets the standard for authenticity, purity, and value. The metaphoric value of gold has always been to set the ultimate standard of comparison - that which is "as good as gold" is that which is permanent, incorruptible, untarnished, and enduring, not to mention beautiful and precious. It can also be refined and purified, and thus participates in a metaphysics of perfectibility. A routine example can be found in John Lydgate's poem "Beware of Doubleness": "O ye wymmen, which bene enclyned/ ... To been as pure as gold y-fined ..."28; or, in Sir Gawain and the Green Knight, "Gawan watz for gode knawen, and as golde pured,/Voyded of vche vylany" [Gawain was known for goodness, and like refined gold, he was devoid of villainy]. ${ }^{29}$ On the other hand, the word "gold" is a metonym meaning "money." Chaucer's most famous metaphor for authenticity is certainly that from the description of the Parson in the General Prologue: "yf gold rust, what shal yren do?/For if a preest be foul,

\footnotetext{
27 For example, on the question as to whether the sly remark about the Merchant in the General Prologue, "Wel koude he in eschaunge sheeldes selle" (1. 278) means he was breaking the law or merely bending it. See Baker, “Gold coins in medieval English literature", p. 286; and Mann, Chaucer and Medieval Estates Satire, p. 10o, respectively.

28 Lydgate, Minor Poems, ed. H.N. MacCracken, vol. 2, p. 442.

29 Sir Gawain and the Green Knight, ed. J.R.R. Tolkien, 1l. 634-35.
} 
on whom we truste,/No wonder is a lewed man to ruste" (505). Gold, obviously, does not rust, and the sense of the metaphor is that it ought not: that priests, of finer quality than their "lewed" flock, should be stable and enduring, and that their substance should be true. Yet elsewhere Chaucer raises the spectre of rusty gold, of gold that morphs and shifts. What does the gold standard mean in Chaucer's poetry?

As early as The House of Fame, gold seems less than certain as the standard for permanent value. The house of the grotesque goddess of Fame "was plated half a foote thikke/Of gold ..." (1345-46). It seems initially, perhaps because of the gold, to represent stable and enduring reputation or fame, but though glittering, it is shaky in substance; it is about shifting appearance rather than permanent value, built on "a feble fundament" [a weak foundation] (1132) of melting ice. Fame is swayed not by permanent value, but by such inducements as the "nobles and sterelynges" (1315) a crowd of people shake out to buy her favour. Even the specie gold metal of the temple is tied to money: it is "fyn as ducat in Venyse", which is to say, 99 per cent pure, like the coin "of which to lite al in my pouche is" (1l. 1348-49). The cash economy erodes the measure of real value and qualifies the metaphoric gold standard of merit.

Chaucer's most famous coin metaphor is in the description of Alisoun in the Miller's Tale. In a metaphoric cornucopia, she is compared to flora and fauna of the burgeoning natural world, the behaviour of young animals, the social stratification of the marriage market, and good food. She is also compared with money: "ful brighter was the shynyng of hire hewe/Than in the Tour the noble forged new" (CT $3255^{-56}$ ). The metaphors combine to show Alisoun as a creature of extraordinary value, a treasure, a hoard - a coin. We have already learned that her husband is jealous, in the typical conjunction of sexual jealousy and avarice, both types of hoarding possessiveness. The sense of the metaphor is that Alisoun glows; she is bright and shiny, a "golden girl" in the usual sense, or as the current slang has it, "she's so money." Certainly the economic tenor of the expression is not lost; Alisoun's "exchangeability" is stressed in a precisely class-conscious assessment of her "value": "she was a prymerole, a piggesneye,/For any lord to leggen in his bedde,/Or yet for any good yeman to wedde" $(3268-70)$. She has wed the yeoman, but as the tale famously demonstrates, that does not mean she is off the sexual circuit. Elizabeth Scala has drawn attention to the metaphor of the noble in relation to the trajectory of the Canterbury Tales; the Knight has just told a "noble" story, as all the pilgrims agree at line 3111. It is noble because of its gravitas and dignity and genre, and also because it concerns actual nobles (aristocrats). By line 3255, the ineffable nobility of a "high sentence" and tale of chivalry has turned into a coin, 
an actual physical object, tangible, glittering, and commercial. ${ }^{30}$ The libidinal economy is here again a money economy.

The noble has received as much attention from literary scholars as from historians. It was a golden coin first minted in 1344 for Edward III, and reminted periodically till 1460 . When on display in the Fitzwilliam Museum, Cambridge, for example, it is certainly an object of beauty in its own right. It was the first successful golden coin in English currency in over 200 years. Peter Spufford's magisterial account locates what he calls the "victory of gold" in currency, in particular of northwest Europe (England) exactly in the mid-14th century. ${ }^{31}$ The noble represents the attempt by the English Crown to intervene in the gold standard previously maintained by the florin and Venetian ducat, and to impose its currency in European trade. The English sterling had been long established as the silver standard. Spufford gives examples from before the victory of golden money of foreign gold coins being treated in England "more as a commodity than a currency" and "used for such strictly uncommercial purposes as prestigious alms-giving by Kings". ${ }^{32}$ The romance Sir Isumbras represents such high-end charity, when Sir Isumbras' unnamed wife, having become a queen, distributes "florins" to beggars, including her husband. ${ }^{33}$ The confusing nature of gold as jewellery or ornament, as prestige commodity in the romance tradition, complicates its becoming money. For example, the word "gold" appears most frequently for Chaucer in the Knight's Tale, where it adorns saddles and gilds statues in the economy of ostentation, as in Thomas Chestre's Sir Launfal, but where it also means money, as when Theseus gives the disguised Arcite "gold to mayntene his degree" (1441). Gold and "gold" continue in an uneasy relation between golden substance and monetary sign, neatly conjoined in Chaucer's sly remark about the physician. He prospered during the plague, "for gold in physic is a cordial" (CT 445), meaning both that money is a welcome thing to the physician, and that specie gold is an ingredient in medicine.

The noble is inscribed with an image of the sword-wielding king in a ship; the ship is supposed to represent Edward's naval victory at Sluys in 1340 and presumably, in the case of mintings for later kings, the perennial intention to return to France. The king is circled by his stylings (which include in most mintings a pretention to the throne of France). The other side has the image of a cross, and an intriguing exergue from Luke 4:31: IHC AUTEM TRANSIENS PER MEDIUM ILLORUM IBAT ("But Jesus passing through their midst went

\footnotetext{
30 Scala, Desire in the Canterbury Tales, p. 10.

31 Spufford, Money, p. 267.

32 Ibid., p. 277.

33 Sir Isumbras, ed. H. Hudson, 1. 540.
} 
his way"). This inscription has caused debate, but I take it to be a strange little charm, apparently against robbery - the wish is that this coin might also pass unnoticed through crowding dangers as Jesus did. So the coin is beautiful, golden, conventionally valuable, and talismanic, all at once. D. Vance Smith has written persuasively of the complex symbolic functions of "a coin intended to signify England's arrival on the continent" both in terms of military conquest and intervention in foreign markets; ${ }^{34}$ Spufford details Edward's attempts to control the influx of foreign gold to England and his success in flooding Europe with nobles. ${ }^{35}$ Thus the "nobles or sterelynges" that appear in Chaucer's writing ${ }^{36}$ are not only standing for good money, reliable money, but also for English money - and Alisoun is an avatar of that.

\section{The Pardoner's and Canon's Yeoman's Tales: The Lure of Gold}

These two stories represent the power of gold to draw people along the path of desire, even at the cost of real economic advantage. Radix malorum est cupiditas: gold is death, is the moral of the story told by the Pardoner. The three revellers, from a tavern in Flanders, following an old man in pursuit of Death, whom they take to be a person, find him in the form of eight bushels of "florins fyne of gold ycoyned rounde" (CT vi l. 770). Two watch the gold while the third is sent for celebratory wine; he poisons the wine to have the gold, but the remaining two kill him to have the gold, then drink the wine, and thus they all find death. The florins here are not necessarily Florentine, since many regimes struck their own coins to the same specification - in other words, a "florin" was not a national coinage speaking directly to Florence as in Dante, but was widely understood to be a matter of its substance, its weight in gold, rather than its signage. In any case, eight bushels is a fortune.

The tale and its end demonstrate three separate economies. The revellers are wasters, in Middle English terms - spenders, gluttons, rioters, gamblers (l. 465-69). They conform to the theory of the tavern as advanced by Andrew Cowell as a paradigm of profit and play. Since they are wasters and revellers, those who enjoy spending and consuming at the expense of earning and getting, they in fact attest to an economy of plenty - waste can only occur when there is something to waste. The Pardoner thus begins his sermon with an attack on gluttony, the sin of senseless and excessive consumption. The riot is

34 Smith, Arts of Possession, p. 124.

35 Spufford, Money, pp. 277 and 286.

36 At Pardoner's Tale ll. 907 and 930; House of Fame 1. 1315; Miller's Tale 1. 3256. 
interrupted by the intrusion of Death, the ultimate figure of an economy of shortage, and the revellers determine to slay him, but in looking for him, they are lured into an economy of shortage, of cupidity. The eight bushels of coins demonstrate only that there can never be enough money, as Gower said; the hoard of gold produces absolute dearth: Death. The vehicle of the men's competitive striving for the coins comes, however, as in the fabliaux, from the remnant of the tavern mentality of wasting - they send for wine. But the celebration is over. The third economic register of the text is in the tail link, in which the Pardoner tries to convert this cautionary tale into more money, disguised as a return to the gift economy of charitable donation. He calls for "nobles or sterlynges,/or elles silver broches, spoones, rynges" (ll. 907-8) in exchange for his pardon, or "Nobles or pens, whiche that be goode and trewe" (1. 930) for kissing his relics, eventually discounting this rate to a mere groat for the Host. Here is the debasement of the very economy of salvation: fraudulent relics and heaven-for-sale as converted into cold, hard specie metal.

As in the Pardoner's Tale, gold is a lure in the Yeoman's tale of the alchemist canon. Here, gold as specie causes real misrecognition of the actual economic transaction taking place. What the alchemist succeeds in doing is selling the promise of gold for money "goode and trewe": actual currency, rather than the metal that might be held to make it "goode". Alchemy, we are told, is the "slydinge science" of multiplication (l. 732); it is an "elvysshe craft" (l. 751), or "elvysshe nyce loore" (1. 842). The only other occurrence of the word "elvish" in Canterbury Tales is in the mock romance Sir Thopas, where it might be expected; here it certainly evokes the fairy origin of gold, though in a version close to demonic, complete with fiends and brimstone. The Yeoman first makes extravagant claims about his master's abilities, saying he could pave the streets with gold, but actually gives a story in which the canon gulls his victims by appearing to make silver from quicksilver. The actual effect of alchemy is that of a reverse Rumpelstiltskin, turning gold into dross. The Yeoman's first theme is impoverishment - the lure of gold and silver as specie metals actually causes poverty; he is heavily in debt "Of gold that I have borwed" to finance the futile attempt to "multiply" it (1. 735). Robert Epstein, in an article that is a model of a detailed approach to the economic study of literature, contrasts Gower's depiction of alchemy in Book IV of Confessio Amantis to Chaucer's, showing that Gower falls on the side of the alchemists, who "insisted they were augmenting the true content of metals through entirely natural processes". ${ }^{37}$ Their work is a kind of refining that results in increase; or it is a smoke-and-mirrors 
process that results in decrease. The irony of the tale is that the greedy will spend money to get gold. The Yeoman stresses a confusion of gold and money, and a concomitant attempt (through alchemy) to separate specie gold from money - and then turn it back into money. Jean-Joseph Goux comments on the fetish character of gold, for gold is excessive in relation to any real economic function, and the fetish is that which obscures or disavows its own origin. ${ }^{38}$ The precious metal thus hides exchange value behind its alluring, attractive surface. The alchemist plays on this fetish character and is not impoverished, but enriched. He is not himself blinded by the lure of gold, but is purely in pursuit of money. His story is, in effect, about how to convert one mark (as a weight of silver) into 40 pounds - the sum he charges for his spurious alchemical recipe. Thus he has himself effected the multiplication he has advertised, though not in the manner claimed.

The swindle in question concerns not gold, but silver, and this modest touch is no doubt central to how the con actually works - not grandiose but achievable alchemy, modest fraud. Interestingly, the confidence needed for the con game is established by a loan of money: the canon borrows a mark and promptly repays it, thus establishing his credit with the priest he is gulling: "And to the preest he took his gold agayn" (1. 1034). It is impossible to tell if the loan was of golden coins, or whether "gold" means simply "money" here. This equivocation is central to the meaning of the tale, which concerns the conversion or exchange of money into "gold" and back again.

In the end, the gulled priest pays the price. By his elvish craft, the alchemist has succeeded in turning a mark of silver into 40 pounds in nobles, that is to say, into golden coin; he has not turned quicksilver into silver, but silver into gold. Epstein argues that the "technology" Chaucer is interested in is not alchemy, but money. ${ }^{39}$ Real value is not in the substance of gold, but in the denominations of money embodied in the golden coin. The tale is an illustration of the effect of inordinate desire for plenty; it is also, perhaps sadly, a demonstration that the "good hope [that] crepeth in oure herte" (1. 870) can be converted or exchanged into money.

It is no doubt wrong to generalize from my three examples to a position about Chaucer's position on gold and golden money; the tales I have emphasized concern a cheating wife and two con men, and if we add the Shipman's Tale, another cheating wife and a suspect merchant. So I do not conclude that the gold standard has rusted for Chaucer. But these configurations of

38 Goux, Symbolic Economies, p. 33.

39 Epstein, "Dismal Science", p. 238. 
money - as shifting, dissolving, and morphing values - provide an investigation of the possibilities inherent in the money economy. Chaucer's metaphoric and narrative money undoes the presumption of any fixity in money; it will proliferate illogically through use, circulation, expenditure, foreign exchange, and swindling.

\section{Conclusions}

In the writings I have discussed, literary critics have seen, in varying degrees, a reflection of the rising mercantile and profit economy in the later Middle Ages. Jean Favier gives an account of the increasing abstraction of wealth, from money to letters of exchange to letters of credit; ${ }^{40}$ such abstraction was seen to unmoor money, like a sign, from any proper referent and towards the shifting values of exchange and circulation that enable "capital". Such a process necessarily took place over several centuries, and it is often difficult to arrive at precise accounts of which part of it is present in literature. ${ }^{41}$ For example, the economies of commodity and gift, of feudal obligation, remain enshrined in the romance genre long after other economies had taken over - but partly because such practices were enshrined in the social imaginary of honour to which literature testifies, they endured in the kind of social practices Martha Howell describes as "gift work". ${ }^{2}$ I have suggested that certain configurations across genres endured in the late Middle Ages, such as the imaginary of money as plenty, while precise readings of different avatars of this trope, such as Smith's reading of Lanval and Sir Launfal, can demonstrate historical specificity.

A major topic in literary criticism has been the analogy between language and money in terms of sign. I return to the view that the sign of money erases difference; it makes unlike things the same in the interest of exchanging them. Thus it can be held to cause the flux and indeterminacy that erodes real value, or, to put it in linguistic terms, that uncouples signifier from signified. This suspicion of the dissolving power of money and its relation to language in medieval literature is found by modern critics everywhere: money economy introduces semiotic flux, change in meanings, fluidity, exchange, instability,

\footnotetext{
$40 \quad$ Favier, Gold and Spices, p. 215.

41 Judith Kellogg (Medieval Artistry and Exchange) locates the rising profit in texts as early as the 11th century and Andrew Cowell (At Play) in the 12th, while Joel Kaye (Economy and Nature) argues for the English fourteenth century.

42 Howell, Commerce before Capitalism, ch. 3. Gift-giving, she argues, establishes honour, which in credit economy in fact means credit, p. 201.
} 
whether this is held to be positive or lamentable. For example, James R. Simpson claims of Trubert (discussed above), that Trubert's "absence of a fixed identity is a sign of the way in which money created a variety of social networks that had not previously existed". ${ }^{43}$ Judith Kellogg sees in the Roman de la Rose a dissolution of real social bonds in the "shift from a gift to a profit economy" characterized by commodification and cash. ${ }^{44}$ Lee Patterson remarks that the Shipman's Tale shows "nothing less than the primary condition of economic man: when the worth of goods is determined solely by their exchange value, then value is radically contingent". ${ }^{45}$ Andrew Cowell asserts that the tavern texts in themselves provide the theory of money as play and change that explains the rising cash economy after the 12th century. Gerhard Joseph's argument about the Shipman's Tale is that just as impossible profits accrue through the circulation of money, so the puns of the tale show an extraordinary surplus value, creating two meanings for one and thus undoing the presumption of a stable referent. R.A. Shoaf states, on the other hand, that anxiety about the possibly unstable nature of monetary and linguistic signs causes Dante and Chaucer to work towards the stabilization of the referent, in a "poetics of reference". 46

I have suggested that golden money complicates the sign theory of money because its substance, not what makes it money, is in conflict with the general equivalency in exchange that is its money-nature. Is the English noble guaranteed by the sign of the king, or by the fineness of its metal? Which aspect truly guarantees the series of values? Goux quotes Marx as finding in gold the fetish character, "the false semblance" the "magic of money" 47 - exactly what we have seen in medieval narratives of money. Gold does not so much obfuscate and hide the shifting meaning of money as attest to the desire that money not shift. At the same time, the becoming-money of gold undoes the "gold standard" of metaphor. Gold, appearing as money, introduces lack, or "imperfection" as Dante argues in Convivio: gold and gems "in themselves considered, are perfect things - not [as] riches, however, but as gold or gems".48 Figurations of money in the literature of the later Middle Ages play along the spectrum between the "substance" of golden coin and the morphing values of pure exchangeability.

\footnotetext{
43 Simpson, Fantasy, Identity and Misrecognition in Medieval French Narrative, p. 229.

44 Kellogg, Medieval Artistry and Exchange, p.158.

45 Patterson, Chaucer and the Subject of History, p. 351.

46 Shoaf, Dante, Chaucer and Currency of the Word, p. 15.

47 Groux, Symbolic Economies, p. 33.

48 Dante, Convivio Iv.xi.
} 
Money in medieval literature appears in all the guises possible in its society, most of which I have passed over in silence. I have tried to discuss some of the main significances assigned to money by medieval writers and modern literary critics. I have concentrated on those manifestations in literature that are less matters of representation than those that perform fully "literary" functions: to provide mythologies, origin stories, and even fantasies of plenty. Money functions inside the "economy" of literature differently than it does in the market. There, it attracts moral commentary, but also libidinal and affective meanings, symbolic and allegorical significance. Literature provides a working through of expenditure and gain, in which justice can be done to the hyper-economies of desire, sex, greed, salvation, and the metaphoric values that attend money in excess of apparent denominations.

\section{Bibliography}

\section{Primary Sources}

Augustine, De Doctrina Christiana, ed. and trans. R.P.H. Green, Oxford, 1995.

Alighieri, Dante The Convivio of Dante Alighieri, trans. P.H. Wicksteed, London, 1912.

Alighieri, Dante Inferno, ed. and trans. A. Esolen, New York, 2007.

Alighieri, Dante Paradise, ed. and trans. A. Esolen, New York, 2007.

Chaucer, G., The Riverside Chaucer, ed. L.D. Benson, 3rd ed., Boston, 1988.

Chestre, Thomas, Sir Launfal, ed. A. Laskaya and E. Salisbury, The Middle English Breton Lays, Kalamazoo, 1995.

Douin de Lavesne, Trubert, fabliau du XIIIe siècle, ed. G. Raynaud de Lage, Geneva, 1971. Gower, J., The English Works of John Gower, ed. G.C. Macaulay, 2 vols. (Early English Text Society, 81-82), London, 1900.

Lydgate, J., The Minor Poems of John Lydgate, ed. H.N. MacCracken, 2 vols. (Early English Text Society, 107 and 192), London, 1911.

Marie de France, Lais, A. Ewert (ed.), Oxford, 1978.

Sir Isumbras, ed. Hudson, H. Four Middle English Romances, Kalamazoo, 2006.

\section{Secondary Literature}

Allen, Valerie, On Farting:Language and Literature in the Middle Ages. Basingstoke, 2007. Amariglio, J., and Ruccio, D.F., 'Literary/cultural 'economies', economic discourse, and the question of Marxism", in Woodmansee and Osteen, The New Economic Criticism, 381-400.

Baker, D.C., "Gold coins in medieval English literature", Speculum 36 (1961), 282-87.

Bertolet, C., Chaucer, Gower, Hoccleve and the Commercial Practices of Late FourteenthCentury London, London, 2013. 
Cowell, A., At Play in the Tavern: Signs, Coins, and Bodies in the Middle Ages, Ann Arbor, 1999 .

Edwards, E., “The economics of justice in Chaucer's Miller's and Reeve's Tales”, Dalhousie Review, 82 (2002): 91-112.

Epstein, R., "Dismal science: Chaucer and Gower on alchemy and economy", Studies in the Age of Chaucer 36 (2014), 209-48.

Favier, J., Gold and Spices: The Rise of Commerce in the Middle Ages, trans. C. Higgitt, New York, 1998 (1987).

Gaunt, S., Gender and Genre in Medieval French Literature, Cambridge, 1995.

Goux, J.-J., Symbolic Economies: After Marx and Freud, trans. J. Curtiss Gage, Ithaca, N.Y., 1990 (1973).

Green, R.F., Poets and Princepleasers: Literature and the English Court in the Late Middle Ages, Toronto, 1980.

Howell, M.C., Commerce before Capitalism, 1300-16oo, Cambridge, 2010.

Joseph, G., "Chaucer's coinage: foreign exchange and the puns of the 'Shipman's Tale", The Chaucer Review 17 (1983), 341-57.

Kaye, J., Economy and Nature in the Fourteenth Century: Money, Market Exchange, and the Emergence of Scientific Thought, Cambridge, 1998.

Kellogg, J., Medieval Artistry and Exchange: Economic Institutions, Society, and Literary Form in Old French Narrative, New York, 1989.

Mann, J., Chaucer and Medieval Estates Satire, Cambridge, 1973.

Mann, J., "Price and value in Sir Gawain and the Green Knight", in M.D. Rasmussen (ed.), Life in Words: Essays on Chaucer, the Gawain-Poet, and Malory, Toronto, 2014, 167-86.

Marshall, J.E., Radix Malorum: The Presence and Function of Money in Medieval Literature, diss. Catholic University of America, 2006.

Mauss, M., "Essai sur le don: forme et raison de l'échange dans les sociétés primitives", L'Année Sociologique, 2nd ser., 1 (1925 for 1923-1924), 30-186.

Patterson, Lee, Chaucer and the Subject of History, Madison, 1991.

Scala, E., Desire in the Canterbury Tales, Columbus, 2015.

Schrift, A.D. (ed.), The Logic of the Gift, New York, 1997.

Shell, M., The Economy of Literature, Baltimore, 1978.

Shoaf, R.A., Dante, Chaucer and Currency of the Word, Norman, Okla., 1983.

Simpson, J.R., Fantasy, Identity and Misrecognition in Medieval French Narrative, Bern, 200o.

Smith, D.V., Arts of Possession: The Middle English Household Imaginary (Medieval Cultures 33), Minneapolis, 2003.

Spufford, P., Money and Its Use in Medieval Europe, Cambridge, 1988. 
Woodmansee, M., and Osteen, M. (eds.), The New Economic Criticism: Studies at the Interface of Literature and Economics, London, 1999.

Woodmansee, M., and Osteen, M., "Taking account of the new economic criticism: an historical introduction", in Woodmansee and Osteen, The New Economic Criticism, 1999, 3-5o. 